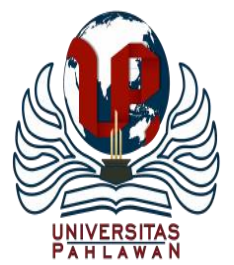

Edukatif : Jurnal Ilmu Pendidikan Volume 3 Nomor 4 Tahun 2021 Halm 2271 - 2278

EDUKATIF: JURNAL ILMU PENDIDIKAN

Research \& Learning in Education

https://edukatif.org/index.php/edukatif/index

\title{
Meta Analisis Model Pembelajaran Project Based Learning terhadap Kreativitas dan Hasil Belajar Siswa di Sekolah Dasar
}

\author{
Yosafat Anton Christian
}

Pogram Studi Pendidikan Guru Sekolah Dasar, Universitas Kristen Satya Wacana, Indonesia E-mail : antonchristian774@gmail.com

\begin{abstract}
Abstrak
Model pembelajaran pada kurikulum 2013 salah satunya adalah Project Based Learning. Model pembelajaran ini berkaitan dengan pembelajaran berbasis proyek. Hingga sekarang ini kemampuan yang dimiliki siswa dalam meningkatkan kreativitas masih dianggap rendah sehingga diharapkan dengan pembelajaran model ini dapat meningkatkan kreativitas peserta didik dalam pembelajaran. Tujuan pada penelitian ini untuk mengetahui pengaruh dari diberlakukannya model pembelajaran berbasis proyek (PjBL) jika ditinjau dari kreativitas dan hasil belajar peserta didik. Peneliti menggunakan metode penelitian deskriptif yaitu dengan menganalisa 20 jurnal artikel sejenis. Penelitian ini dilakukan dengan mencari besaran pengaruh (Effect Size) untuk mengetahui dampak diberlakukannya model pembelajaran pembelajaran PjBL terhadap kreativitas dan hasil belajar peserta didik. Berdasarkan hasil analisa yang dilakukan peneliti hasil nilai effect size sebesar 1,063 dan dapat dilihat dari tabel interpretasi Cohen's. Dengan demikian bahwa model pembelajaran Project Based Learning berpengaruh sangat besar dalam meningkatkan kreativitas dan hasil belajar peserta didik di Sekolah Dasar.
\end{abstract}

Kata Kunci: Project Based Learning, kreativitas, hasil belajar, Siswa Sekolah Dasar.

\begin{abstract}
One of the learning models in the 2013 curriculum is Project Based Learning. This learning model is related to project-based learning. Until now, the ability of students to increase creativity is still considered low, so it is hoped that this learning model can increase the creativity of students in learning. The purpose of this study was to determine the effect of the implementation of the project-based learning model (PjBL) in terms of creativity and student learning outcomes. Researchers used descriptive research methods, namely by analyzing 20 journal articles of the same type. This research was conducted by looking for the effect size to determine the impact of the implementation of the PjBL learning model on creativity and student learning outcomes. Based on the results of the analysis conducted by the researcher, the effect size value is 1.063 and can be seen from Cohen's interpretation table. Thus, the Project Based Learning learning model has a very large effect in increasing the creativity and learning outcomes of students in elementary schools.
\end{abstract}

Keywords: Project Based Learning, creativity, learning outcomes, elementary school students.

Copyright (c) 2021 Yosafat Anton Christian

$\triangle$ Corresponding author

Email : antonchristian774@gmail.com

DOI : $\overline{\text { https://doi.org/10.31004/edukatif.v3i4.1207 ISSN 2656-8071 (Media Online) }}$ 
2272 Meta Analisis Model Pembelajaran Project Based Learning terhadap Kreativitas dan Hasil Belajar Siswa di Sekolah Dasar - Yosafat Anton Christian

DOI: https://doi.org/10.31004/edukatif.v3i4.1207

\section{PENDAHULUAN}

Proses pembelajaran merupakan hubungan timbal balik antara guru dengan peserta didik. Pembelajaran ini yang dilaksanakan oleh guru secara terstruktur dan terencana. Dengan adanya hubungan timbal balik antara peserta didik dengan guru untuk mencapai tujuan pembelajaran. Dengan demikian tujuan pembelajaran akan tercapai secara optimal. Diperkuat dengan pendapat ahli menurut (Hardini \& Puspitasari, 2012) "Pembelajaran adalah suatu aktivitas yang dengan sengaja untuk memodifikasi berbagai kondisi yang diarahkan untuk tercapainya suatu tujuan, yaitu tercapainya tujuan kurikulum". Pada kenyataannya, sekarang ini sedang terhambat karena maraknya virus Corona. Virus ini sangat membahayakan karena dapat menular begitu cepat. Virus ini juga menyerang imun manusia (Amalia et al., 2020). Menanggapi hal ini menteri pendidikan mengeluarkan Surat Edaran yang berisi perintah untuk melakukan pembelajaran jarak jauh atau secara daring. Hal ini tertuang pada Surat Edaran Kemendikbud No. 4 Tahun 2020. (Surat Edaran Mendikbud Nomor 4 Tahun 2020 | GTKDIKMENDIKSUS | 2020, n.d.) Pembelajaran jarak jauh ini dapat membuat siswa bosan dan jenuh dalam belajar serta membuat kreativitas peserta didik rendah (Agustina et al., 2019). Peserta didik hanya belajar secara monoton dengan memberikan tugas melalui WhatsApp saja (Susilowati, 2020). Kendala-kendala tersebut membuat pembelajaran dirasa kurang efektif dan efisien karena kurang sesuai dengan kondisi lingkungan peserta didik (Ngurah Laba Laksana et al., 2016).

Kreativitas merupakan faktor yang perlu ditingkatkan karena sangat mempengaruhi proses berfikir peserta didik dalam proses pembelajaran. Kreativitas atau kemampuan berfikir ini digunakan untuk menciptakan atau menghasilkan sesuatu yang baru, berbeda, belum ada sebelumnya yang berupa suatu gagasan, ide, hasil karya serta respon dari situasi yang tidak terduga (Gunawan \& Farid, 2014). Kreativitas juga sebagai kemampuan untuk berfikir tentang cara baru, dan tidak biasa, datang dengan solusi yang unik (Habibah, 2016). Dengan demikian guru perlu menggunakan model pembelajaran yang sesuai dengan kebutugan peserta didik. Model pembelajaran ini digunakan guru sebagai kerangka sistematis yang menggambarkan prosedur dalam menerapkan pengalaman pembelajaran untuk mencapai tujuan pembelajaran (Jamil 2013).

Proses pembelajaran yang dapat menunjang kreativitas peserta didik serta dapat meningkatkan hasil belajar salah satunya dapat menggunakan model pembelajaran Project Based Learning karena dalam kegiatan pembelajaran siswa diminta untu menguraiakan permasalahan untuk dapat menginvestigasi (Mulyasa 2015). Project Based Learning menekankan belajar kontekstual melalui kegiatan-kegiatan yang kompleks (Trianto, 2014). Pengalaman belajar peserta didik maupun konsep dibangun berdasarkan produk yang dihasilkan dalam proses pembelajaran berbasis proyek (Supriyanto, 2020). Kerja proyek ini menuntun peserta didik untuk merancang, memecahkan masalah, membuat keputusan, melakukan kegiatan investigasi, serta memberikan kesempatan peserta didik untuk bekerja secara mandiri. Kelebihan model pembelajaran Project Based Learning yaitu dapat meningkatkan motivasi belajar, dapat menumbuhkan keaktifan peserta didik, meningkatkan kreativitas belajar peserta didik serta dapat meningkatkan kemampuan pemecahan masalah (Daryanto dan Raharjo, 2012 : 162).

Model pembelajaran Project Based Learning ini efektif digunakan untuk pembelajaran karena dapat mendorong kreativitas belajar siswa sehingga dapat meningkatkan hasil belajarnya. Hal ini dibuktikan dengan penelitian yang telah dilakukan sebelumnya. Penelitian yang pertama dilakukan oleh (Rohana \& Wahyudin, 2017) yaitu melakukan penelitian dengan judul "Project Based Learning untuk meningkatkan berfikir kreatifitas siswa SD pada materi makanan dan kesehatan". Penelitian ini menunjukan bahwa terdapat peningkatan yang signifikan pada kreatifitas dan hasil belajar. Penelitian selanjutnya adalah penelitian yang dilakukan oleh (Surya et al., 2018) dengan penelitian yang berjudul "Penerapan Model Pembelajaran Project Based Learning (PjBL) untuk meningkatkan hasil belajar dan kreatifitas siswa kelas 3". Pada penelitian ini disimpulkan hasil belajar meningkat setelah menggunakan pembelajaran dengan model Project Based 
Learning. Selain itu dengan model ini dapat meningkatkan kreatifitas siswa. Selain itu penelitian yang dilaksanakan oleh (Maula, Prihatin, and Fikri 2014) dengan judul "Pengaruh Model PjBL (Project-Based Learning) terhadap Kemampuan Berpikir Kreatif dan Hasil Belajar Siswa pada Materi Pengelolaan Lingkungan". Pada penelitian ini juga mengalami peningkatan hasil belajar yang signifikan.Penelitian yang dilakukan (Widyastuti, Utami, and Uliyanti 2016) dengan judul "Pengaruh Model Project Based Learning Terhadap Hasil Belajar Pendidikan Kewarganegaraan Di Kelas IV SD” juga mengalami peningkatan pada hasil belajarnya. Selain itu penelitian lain juga dilakukan oleh (Dewi, Garminah, and Pudjawan 2013) dengan judul "Pengaruh Pembelajaran Berbasik Proyek (Project- Based Learning) terhadap Hasil Belajar IPA Siswa Kelas IV SD N 8 Banyuning" dan terdapat peningkatan yang cukup besar pada hasil belajar peserta didik. Pada penelitian yang dilakukan (Wilma Muzria 2020) dengan judul "Pengaruh Model Project Based Learning terhadap Hasil Belajar Siswa pada Pembelajaran Tematik Terpadu Sekolah Dasar" hasil yang didapat setelah menggunakan model pembelajaran Project Based Learning mengalami peningkatan.

Berdasarkan penelitian yang telah dilakukan sebelumnya, banyak penelitian yang berpengaruh besar dalam meningkatkan kreativitas dan hasil belajar. Namun melihat kenyataannya di masa pandemic ini peserta didik cenderung malas dan adanya penurunan kreativitas. Maka peneliti ingin melakukan penelitian tentang "Meta Analisis Model Pembelajaran Project Based Learning Terhadap Kreativitas dan Hasil Belajar Siswa di Sekolah Dasar". Peneliti menganalisis artikel ilmiah sebanyak 20 jurnal dengan pokok pembahasan yang sama untuk dicari besaran pengaruhnya (Effect Size).

\section{METODE PENELITIAN}

Pada penelitian ini menggunakan jenis penelitian meta analisis. Meta analisis adalah pengkajian terhadap hasil-hasil penelitian yang sejenis (Sriawan and Utami, 2015). Populasi yang digunakan dalam penelitian ini adalah Project Based Learning. Sedangkan sampel yang diambil adalah bagaimana pengaruh yang diberikan model pembelajaran Project Based Learning terhadap kreativitas peserta didik dan hasil belajarnya. Peneliti menggunakan proses pengumpulan data dengan cara mencari artikel melalui google schoolar dengan kata kunci penelusuran "Project Based Learning, kreativitas dan hasil belajar siswa SD" sebanyak 20 artikel yang sejenis. Selanjutnya data yang dihasilkan dari 20 artikel tersebut dihitung untuk mencari besar effect size dari penerapan model pembelajaran Project Based Learning terhadap kreativitas dan hasil belajar siswa SD. Kemudian Effect size dihitung untuk mencari besar pengaruh dari model pembelajaran Project Based Learning terhadap kreativitas dan hasil belajar siswa, adapun rumus perhitungan effect size adalah sebagai berikut:

$$
d=\frac{M_{\text {posttest }}-M_{\text {pretest }}}{\sqrt{\frac{\left(S D_{\text {pretest }}{ }^{2}+S D_{\text {posttest }}{ }^{2}\right)}{2}}}
$$

Keterangan:

$$
\begin{array}{ll}
\mathrm{D} & =\text { Effect } \text { Size } \\
\mathrm{M}_{\text {pretest }} \quad=\text { mean pretest } \\
\mathrm{M}_{\text {posttest }} \quad=\text { mean posttest } \\
\mathrm{SD}_{\text {pretest }}=\text { standar deviasi pretest } \\
\mathrm{SD}_{\text {posttest }}=\text { standar deviasi posttes }
\end{array}
$$


2274 Meta Analisis Model Pembelajaran Project Based Learning terhadap Kreativitas dan Hasil Belajar Siswa di Sekolah Dasar - Yosafat Anton Christian

DOI: https://doi.org/10.31004/edukatif.v3i4.1207

Tabel 1. Interpretasi Effect Size

\begin{tabular}{cc}
\hline Effect Size & Interpretasi \\
\hline $0<\mathrm{d}<0,2$ & Kecil \\
\hline $0,2<\mathrm{d} \leq 0,5$ & Sedang \\
\hline $0,5<\mathrm{d} \leq 0,8$ & Besar \\
\hline $\mathrm{d}>0,8$ & Sangat Besar \\
\hline
\end{tabular}

\section{HASIL DAN PEMBAHASAN PENELITIAN}

Pada penelitian menggunakan metode meta analisis yang bertujuan untuk mengetahui besarnya pengaruh model model pembelajaran Project Based Learning terhadap kreativitas dan hasil belajar siswa. Penelitian ini menganalisis pengaruh (Effect Size) yang dihasilkan dari model pembelajaran PjBL. Effect size menunjukkan pengaruh antara dua variabel yaitu variabel bebas dan variable terikat. Variabel bebas yang diteliti adalah model pembelajaran Project Based Learning, sedangkan variabel terikatnya adalah kreativitas dan hasil belajar peserta didik Sekolah Dasar. Peneliti menggunakan 20 artikel yang telah dilakukan sebelumnya. Artikel ini dideroleh melalui google scholar yang terbit pada tahun 2014-2021. Artikel ini kemudian dianalisa kemudian dihitung dengan menuungakan SPSS. Hasil mengkaji ini kemudian disimpulkan dengan cara mendiskripsikannya secara kuantitatif maupun kualitatif.

Tabel 2. Presentase Peningkatan Kreativitas dan Hasil Belajar Siswa SD

\begin{tabular}{cccccc}
\hline \multirow{2}{*}{ No } & Kode Data & \multicolumn{4}{c}{ Pengaruh Hasil Belajar } \\
\cline { 3 - 6 } & & Pretest & Post Test & Gain & Gain \% \\
\hline 1 & Y1 & 1.88 & 3.50 & 1.62 & $96,8 \%$ \\
\hline 2 & Y2 & 50,86 & 84,34 & 33,48 & $65,82 \%$ \\
\hline 3 & Y3 & 57.56 & 82.46 & 24,9 & $43,25 \%$ \\
\hline 4 & Y4 & 69,25 & 84,67 & 15,42 & $22,26 \%$ \\
\hline 5 & Y5 & 48,48 & 70,28 & 21,8 & $44,96 \%$ \\
\hline 6 & Y6 & 47,5 & 83,5 & 36 & $75,78 \%$ \\
\hline 7 & Y7 & 55,75 & 77,9 & 22,15 & $39,73 \%$ \\
\hline 8 & Y8 & 38,2 & 81,6 & 43,4 & $113,61 \%$ \\
\hline 9 & Y9 & 58,67 & 78,3 & 19,63 & $33,45 \%$ \\
\hline 10 & Y10 & 13,61 & 22,15 & 8,54 & $62,74 \%$ \\
\hline 11 & Y11 & 17,27 & 22,07 & 4,8 & $26,86 \%$ \\
\hline 12 & Y12 & 50,86 & 81,57 & 30,71 & $60,38 \%$ \\
\hline 13 & Y13 & 53.28 & 82,50 & 29,22 & $54,84 \%$ \\
\hline 14 & Y14 & 54 & 75 & 21 & $38,88 \%$ \\
\hline 15 & Y15 & 71,1 & 82,6 & 11,5 & $16,17 \%$ \\
\hline 16 & Y16 & 32,25 & 61 & 28,75 & $89,14 \%$ \\
\hline 17 & Y17 & 64,86 & 80,43 & 15,57 & $24 \%$ \\
\hline 18 & Y18 & 57,04 & 83,16 & 26,12 & $45,79 \%$ \\
\hline 19 & Y19 & 43 & 77,6 & 34,6 & $80,46 \%$ \\
\hline 20 & Y20 & 29.58 & 58.00 & 28,58 & $96,61 \%$ \\
\hline & Rata-rata & 50,86 & 80,43 & 24,9 & $56,56 \%$ \\
\hline & & & & &
\end{tabular}


2275 Meta Analisis Model Pembelajaran Project Based Learning terhadap Kreativitas dan Hasil Belajar Siswa di Sekolah Dasar - Yosafat Anton Christian

DOI: https://doi.org/10.31004/edukatif.v3i4.1207

Berdasarkan hasil analisis data dari sejumlah jurnal, pada Tabel 2 dapat dilihat bahwa Model pembelajaran Project Based Learning dapat meningkatkan kreativitas dan hasil belajar. Terdapat peningkatan hasil belajar dengan rata-rata sebesar 56,56\% mulai dari peningkatan terendah $16,17 \%$ sampai yang tertinggi 113,61 \%. Sementara hasil belajar rata-rata sebelum dan sesudah menggunakan metode Project Based Learning mengalami peningkatan yang signifikan yaitu sebesar $56,56 \%$. Hal ini ditunjukan dari hasil analisis uji beda.

Tabel 3. Paired Samples Statistics

\begin{tabular}{ccccc}
\hline & & Mean & N & Std. Deviation \\
\hline \multirow{2}{*}{ Pair 1 } & Pretest & 45,75 & 20 & 18,57897 \\
\cline { 2 - 5 } & Post Test & 68,6315 & 20 & 24,09913 \\
\hline
\end{tabular}

Berdasarkan tabel diatas menunjukan peningkatan kreativitas dan hasil belajar pesera didik dengan menggunakan model pembelajaran Project Based Learning. Hal ini ditunjukan nilai yang diperoleh sebelum menggunakan model pembelajaran yakni sebesar 45,75 kemudian setelah menggunakan model pembelajaran Project Based Learning rata-rata nilai yang diperoleh adalah sebesar 68,6315. Dengan demikian artinya terdapat peningkatan sebesar 18,57897.

Tabel 4. Paired Samples Corelations

\begin{tabular}{ccccc}
\hline & & N & Correlation & Sig. \\
\hline Pair 1 & Pretest \& Post Test & 20 & 0.901 & .000 \\
\hline
\end{tabular}

Hasil pada tabel diatas menunjukan adanya relasi antara nilai rata-rata kreativitas dan hasil belajar peserta didik sebelum menggunakan model pembelajaran Project Based Learning dan sesudah menerapkan model pembelajaran Project Based Learning. Hasil uji hipotesis, Ho= tidak terdapat perbedaan yang berarti terhadap kreativitas dan hasil belajar siswa sebelum pembelajaran dengan model pembelajaran berbasis proyek $(\mathrm{PjBL})$, sedangkan untuk $\mathrm{H1}=$ terdapat perbedaan yang berarti kreativitas dan hasil belajar siswa sebelum pembelajaran dengan menerapkan model pembelajaran berbasis proyek (PjBL) dan sesudah menerapkan pembelajaran model pembelajaran berbasis proyek (PjBL) dari tabel 4 tampak bahwa nilai Sig $(0,00)<\alpha(0,05)$.

Tabel 5. Paired Samples Test

Paired Differences

95\% Confidence

Interval of the

Difference

\begin{tabular}{|c|c|c|c|c|c|c|c|c|c|}
\hline & & Mean & $\begin{array}{c}\text { Std. } \\
\text { Deviation }\end{array}$ & $\begin{array}{l}\text { Std. } \\
\text { Error } \\
\text { Mean }\end{array}$ & Lower & Upper & $\begin{array}{c}\mathrm{T} \\
\text { hitung }\end{array}$ & $\mathrm{df}$ & $\begin{array}{l}\text { Sig. } \\
(2- \\
\text { tailed }\end{array}$ \\
\hline Pair 1 & $\begin{array}{l}\text { Pre_Test- } \\
\text { Post_Test }\end{array}$ & $-2,8815$ & 18,57897 & 1.802 & $-29,038$ & $-17,258$ & 9,376 & 38 & .000 \\
\hline
\end{tabular}

Berdasarkan tabel diatas nilai $\mathrm{t}$ hitung $=9,376>\mathrm{t}$ tabel $=2,057$ sehingga Ho di tolak. Jadi, dapat disimpulkan bahwa terdapat perbedaan yang signifikan hasil belajar siswa sebelum dan sesudah menggunakan model pembelajaran Project Based Learning. Untuk menyimpulkan secara keseluruhan pengaruh dari penerapan model pembelajaran Project Based Learning terhadap kreativitas dan hasil belajar siswa sekolah dasar maka langkah terakhir adalah menghitung nilai effect size, berikut hasil perhitungan nilai effect size : 
2276 Meta Analisis Model Pembelajaran Project Based Learning terhadap Kreativitas dan Hasil Belajar Siswa di Sekolah Dasar - Yosafat Anton Christian

DOI: https://doi.org/10.31004/edukatif.v3i4.1207

$d=\frac{M_{\text {posttest }}-M_{\text {pretest }}}{\sqrt{\frac{\left(S D_{\text {pretest }}{ }^{2}+S D_{\text {posttest }}{ }^{2}\right)}{2}}}$

$d=\frac{68,6315-45,75}{\sqrt{\frac{\left(18,5789^{2}+24,0991^{2}\right)}{2}}}$

$d=\frac{22,881}{\sqrt{\frac{345,1755+580,7666}{2}}}$

$d=\frac{22,881}{\sqrt{\frac{925,9421}{2}}}$

$d=\frac{22,881}{\sqrt{462,97105}}$

$d=\frac{22,881}{21,516}$

$d=1,063$

Berdasarkan hasil perhitungan yang telah dilakukan oleh peneliti menggunakan rumus uji effect size diatas skor yang diperoleh sebesar 1,0633 yang menunjukan bahwa hasil yang diperoleh lebih besar dari 0,8 yang apabila dilihat dari Tabel 1. Interpretasi Effect Size nilai yang lebih besar daripada 0,8 artinya masuk dalam kategori sangat besar. Sehingga dapat disimpulkan bahwa model pembelajaran Project Based Learning memiliki pengaruh yang besar terhadap kreativitas dan hasil belajar peserta didik Sekolah Dasar.

Hasil Output Paired-Sample T Test pada Tabel 3 menunjukkan bahwa model pembelajaran Project Based Learning dapat meningkatkan kreativitas dan hasil belajar peserta didik. Kemudian pada Tabel 4 terlihat bahwa adanya relasi antara hasil kemampuan pemecahan masalah matematika rata-rata sebelum dengan sesudah menerapkan model pembelajaran Project Based Learning yakni sebesar 45,75 kemudian setelah menggunakan model pembelajaran Project Based Learning rata-rata nilai yang diperoleh adalah sebesar 68,6315. Dengan demikian artinya terdapat peningkatan sebesar 18,57897. Kemudian pada Tabel 4 terlihat bahwa adanya relasi yakni meningkatnya kreativitas dan hasil belajar dengan rata-rata sebelum dengan sesudah menerapkan model pembelajaran Project Based Learning sebesar 0,901. Hasil uji hipotesis, H0 = tidak terdapat perbedaan yang signifikan kreativitas dan hasil belajar siswa sebelum pembelajaran menggunakan model pembelajaran Project Based Learning dan $\mathrm{H} 1$ = terdapat perbedaan yang signifikan signifikan kreativitas dan hasil belajar siswa sebelum pembelajaran menggunakan model pembelajaran Project Based Learning. Tabel 5 menunjukkan nilai Sig. (2-tailed) $(0,000) \& 1 t ; \alpha(0,05)$ dan thitung $=-9,376$ ttabel $=2.093$. Sehingga Ho di tolak. Jadi, dapat disimpulkan bahwa terdapat perbedaan yang signifikan peningkatan kreativitas dan hasil belajar siswa sebelum pembelajaran menggunakan model pembelajaran Project Based Learning. Hasil uji Effect Size dengan menggunakan Uji T dapat dilihat dari hasil Paired Sample Test terdapat hasil yang tertera pada kolom Mean sebesar 45,75 dan Standart Deviation sebesar 18,57897 dan memiliki nilai sig 0,000. Maka besaran Effect Size yang diperoleh adalah sebesar 1,063dan dapat dilihat dari tabel interpretasi Cohen's bahwa model Pembelajaran Project Based Learning berpengaruh sangat besar terhadap peningkatan kreativitas dan hasil belajar di Sekolah Dasar. 
2277 Meta Analisis Model Pembelajaran Project Based Learning terhadap Kreativitas dan Hasil Belajar Siswa di Sekolah Dasar - Yosafat Anton Christian

DOI: https://doi.org/10.31004/edukatif.v3i4.1207

\section{KESIMPULAN}

Berdasarkan hasil analisis diatas dapat disimpulkan bahwa model pembelajaran Project Based Learning memiliki pengaruh sangat besar dalam meningkatkan kreativitas dan hasil belajar siswa. Hal ini berdasarkan hasil perhitungan yang dilakukan peneliti, yakni dari hasil awal dengan rata-rata 45,75 kemudian menjadi 68,6315. Dengan demikian terdapat perbedaan yang signifikan hasil belajar siswa sebelum dan sesudah menggunakan model pembelajaran Project Based Learning. Selain itu hasil perhitungan yang telah dilakukan oleh peneliti menggunakan rumus uji effect size diperoleh skor sebesar 1,0633 yang menunjukan bahwa hasil yang diperoleh lebih besar dari 0,8 yang artinya masuk dalam kategori sangat besar. Maka model pembelajaran Project Based Learning efektif digunakan dalam pembelajaran guna meningkatkan kreativitas dan hasil belajar peserta didik di masa pandemi.

\section{DAFTAR PUSTAKA}

Agustina, P., Bahri, S., Program, A. B., Bimbingan, S., Konseling, D., Keguruan, F., \& Pendidikan, I. (2019). Analisis Faktor Penyebab Terjadinya Kejenuhan Belajar Pada Siswa Dan Usaha Guru Bk Untuk Mengatasinya. Jurnal Ilmiah Mahasiswa Bimbingan Dan Konseling, 4(1). Http://Www.Jim.Unsyiah.Ac.Id/Pbk/Article/View/7153

Amalia, L., Irwan, I., \& Hiola, F. (2020). Analisis Gejala Klinis Dan Peningkatan Kekebalan Tubuh Untuk Mencegah Penyakit Covid-19. Jambura Journal Of Health Sciences And Research, 2(2), 71-76. Https://Doi.Org/10.35971/Jjhsr.V2i2.6134

Daryanto Dan Raharjo, M. (2012). No Titlemodel Pembelajaran Inovatif. Gava Media 3

Dewi, Ni Kt Nik Aris, Ni Ny Garminah, And Kt Pudjawan. 2013. "Pengaruh Model Pembelajaran Berbasis Poyek ( Project Based Learning ) Terhadap Hasil Belajar IPA Siswa Kelas IV SDN 8 Banyuning." Mimbar PGSD Undiksha 1 (1): 1-10.

Gunawan, L., \& Farid, M. (2014). Motivasi Intrinsik, Pola Asuh Orangtua Demokratis Dan Kreativitas Anak Sekolah Dasar. Persona:Jurnal Psikologi Indonesia, Https://Doi.Org/10.30996/Persona.V3i02.378

Habibah, U. (2016). Hubungan Kreativitas Dengan Kemampuan Problem Solving Pada Siswa Di Mts Al Musthofa Mojokerto.

Hardini, I., \& Puspitasari, D. (2012). Strategi Pembelajaran Terpadu. Yogyakarta: Familia.

Jamil, Suprihatiningsih. 2013. "Strategi Pembelajaran Teori Dan Aplikasi." Ar-Ruzz Media 2 (1): 35-44.

Maula, Milla Minhatul, Jekti Prihatin, And Kamalia Fikri. 2014. "Pengaruh Model Pjbl ( Project-Based Learning ) Terhadap Kemampuan Berpikir Kreatif Dan Hasil Belajar Siswa Pada Materi Pengelolaan Lingkungan." Jurnal Kajian Pendidikan Dan Hasil Penelitian 1 (2): 1-6.

Mulyasa, Enco. 2015. "Menjadi Guru Profesional, Menciptakan Pembelajaran Kreatif Dan Menyenangkan.”

Ngurah Laba Laksana, D., Agus Wawan Kurniawan, P., \& Niftalia, I. (2016). Pengembangan Bahan Ajar Tematik Sd Kelas Iv Berbasis Kearifan Lokal Masyarakat Ngada. In Jurnal Ilmiah Pendidikan Citra Bakti (Vol. 3, Issue 1). Http://Www.Ejournal.Citrabakti.Ac.Id/Index.Php/Jipcb/Article/View/74

Rohana, R. S., \& Wahyudin, D. (2017). Project Based Learning Untuk Meningkatkan Berpikir Kreatifsiswa Sd Pada Materi Makanan Dan Kesehatan. Jurnal Penelitian Pendidikan, 16(3), 235-243. Https://Doi.Org/10.17509/Jpp.V16i3.4817

Sriawan, \& Utami, N. S. (2015). Pemetaan Penelitian Mahasiswa Program Studi Pendidikan Guru Sekolah Dasar Pendidikan Jasmani Tahun 2013-2015. Jurnal Pendidikan Jasmani Indonesia, 11(2), 82-87.

Supriyanto, D. (2020). Pembelajaran Terpadu. In Koran Kompas Online. FKIP Universitas Pasundan. 
2278 Meta Analisis Model Pembelajaran Project Based Learning terhadap Kreativitas dan Hasil Belajar Siswa di Sekolah Dasar - Yosafat Anton Christian

DOI: https://doi.org/10.31004/edukatif.v3i4.1207

Surat Edaran Mendikbud Nomor 4 Tahun 2020| Gtkdikmendiksus | 2020. (N.D.). Retrieved March 24, 2021, From Http://Pgdikmen.Kemdikbud.Go.Id/Read-News/Surat-Edaran-Mendikbud-Nomor-4-Tahun-2020

Surya, A. P., Relmasira, S. C., \& Hardini, A. T. A. (2018). Penerapan Model Pembelajaran Project Based Learning (Pjbl) Untuk Meningkatkan Hasil Belajar Dan Kreatifitas Siswa Kelas Iii Sd Negeri Sidorejo Lor 01 Salatiga. Jurnal Pesona Dasar, 6(1). Https://Doi.Org/10.24815/Pear.V6i1.10703

Susilowati, E. (2020). Bagaimana Pembelajaran Daring Di Tengah Wabah Covid 19 Melalui. In Jurnal Pendidikan Matematika Raflesia (Vol. 05, Issue 03). Https://Doi.Org/10.33449/JPMR.V5I3.12896

Trianto. (2014). Mendesain Model Pembelajaran Inovatif, Progresif, Dan Kontekstual. Prenada Media.

Widyastuti, I, S Utami, And E Uliyanti. 2016. "Pengaruh Model Project Based Learning Terhadap Hasil Belajar Pendidikan Kewarganegaraan Di Kelas IV SD.” Jurnal Pendidikan Dan ... Https://Jurnal.Untan.Ac.Id/Index.Php/Jpdpb/Article/View/16752.

Wilma Muzria, Tin Indrawati. 2020. "Pengaruh Model Project Based Learning (PJBL) Terhadap Hasil Belajar Siswa Di Sekolah Dasar.” Jurnal Basicedu 5 (1): 327-33. Https://Doi.Org/10.31004/Basicedu.V5i1.684. 